\title{
Genetic Diversity Analysis in Diversified CMS and Restorer Lines in Sunflower (Helianthus annuus L.)
}

\author{
C. Nandini ${ }^{1 *}$, Y. G. Shadakshari ${ }^{1}$, Pushpa Doddaraju ${ }^{2}$, \\ K.T. Puttarangaswamy ${ }^{1}$ and Vijay Kumar ${ }^{1}$ \\ ${ }^{1}$ University of Agricultural Sciences, GKVK, Bengaluru, Karnataka, India \\ ${ }^{2}$ University of Horticultural Sciences, Bagalkot, Karnataka, India \\ *Corresponding author
}

\section{A B S T R A C T}

In order to develop improved breeding lines having superior yield and oil content, it is essential to have genetically diverse parental lines. Hence, an attempt was made to find out genetic divergence of forty five breeding lines for eleven traits in sunflower. To assess the

Keywords

Sunflower, $\mathrm{D}^{2}$

statistics, Genetic divergence.

Article Info

Accepted:

26 September 2017

Available Online:

10 October 2017 genetic divergence among the 45 genotypes in sunflower, Mahalanobis $\mathrm{D}^{2}$ statistics was applied for eleven traits. 45 parental genotypes were grouped into six clusters based on $\mathrm{D}^{2}$ values. Among the clusters, cluster I was the largest with 32 parents followed by cluster II with 9 genotypes. Clusters III, IV, V and VI had one genotype each. The maximum diversity was recorded between cluster IV and V (1204.09) followed by cluster VI and V (894.01). Hence parents present in these clusters can be made use in hybridization programme, they might give high heterotic response and wider segregations after hybridization. The study revealed that maximum contribution to divergence was made by plant height, seed yield per plant and oil content. Cluster I composed of restorer genotypes which are having higher mean value for volume weight. RHA-91, which was included in cluster III recorded maximum mean value for oil content. Cluster V (CMS109B) showed maximum mean value for oil yield and seed filling per cent. Based on cluster mean values for a given characters, we can select highly divergent genotypes from the respective clusters and can be used in hybridization work.

\section{Introduction}

Sunflower is an important edible oilseed crop of the world. The crop is grown under diverse agro-production situations, crossing climatic and geographic boundaries which necessitated the development of more productive hybrids of diverse duration. Development of hybrid is of much value for increasing the production of sunflower. For efficient hybridization programme,

Genetic diversity among parents is a prerequisite to develop heterotic hybrids in any crop. Genetic diversity between populations or genotypes indicates the differences in their gene frequencies, which is directly related to extent of heterosis exhibited among them. Genetic diversity is of major interest to plant breeders, more diverse the parents, greater are the chances of obtaining heterotic expression in $F_{1}$ with possibility of broad spectrum of variability in segregating generations. The $\mathrm{D}^{2}$ statistic (Murty and Arunachalam, 1966) has been found to be a powerful tool to estimate genetic divergence among population. 
Genetic divergence and grouping of genotypes into different clusters were already reported (Irene Priyadarshini, (1999); Anuradha et al., (2004); Reddy et al., (2004); Loganathan et al., (2006); Mahalaksmi et al., (2006)). Hence, the present study was an attempt to know magnitude of diversity present in forty five parental genotypes for yield and yield related component traits in sunflower.

\section{Materials and Methods}

The material for the present study consisted of 45 parental lines including restorer and diversified CMS lines of sunflower (Table 1). The experiment was conducted at Zonal Agricultural Research Station, UAS, GKVK, Bangalore. Each genotype was sown in two rows of $3 \mathrm{~m}$ length with spacing of $60 \mathrm{~cm}$ between rows and $30 \mathrm{~cm}$ between plants. The experiment was laid out in a Randomized Block Design with two replications. In each genotype, five plants were randomly selected and used for collection of data on eight characters viz., days to fifty percent flowering, plant height $(\mathrm{cm})$, head diameter $(\mathrm{cm})$, stem diameter, Seed filling percentage, hull content, volume weight (g), hundred seed weight $(\mathrm{g})$, oil content $(\%)$, seed yield per plant (g) and oil yield ( $\mathrm{kg} / \mathrm{ha})$. The data were subjected to statistical analysis using Mahalanobis $\mathrm{D}^{2}$ statistic (Mahalanobis, 1936) and Toucher's method as described by Rao (1952) for determining group constellation.

\section{Results and Discussion}

Inter crossing of divergent groups would lead to genetic base in the base population and greater opportunities for crossing over to occur, which intern may release hidden variability by breaking close linkage (Thoday, 1960). The progenies derived from such crosses were expected to show wide variability, providing greater scope for isolating transgressive segregants in the advanced generations. Hence these genotypes may be used repeatedly in the crossing programmes to recover transgressive segregants, which can be either released as variety or can be utilized in the genetic enhancement of sunflower crop.

In the present study, all the forty five parental lines were grouped into six clusters. Cluster I was the largest comprising of 32 genotypes followed by cluster II with nine genotypes and clusters III, IV, V, VI with one genotype each (Table 2). The average intra and inter cluster $\mathrm{D}^{2}$ values are presented in Table 3 . Minimum inter cluster $\mathrm{D}^{2}$ value was observed between cluster V and cluster VI (894.01) indicating the close relationship among the genotypes included in this cluster. Maximum inter cluster $\mathrm{D}^{2}$ value was observed between cluster IV and cluster V (1204.09) followed by cluster III and cluster II and cluster II and cluster I. cluster VI and cluster II included female parents and remaining clusters consisted of restorer lines. Genotypes in cluster II and IV are most diverse as indicated by $\mathrm{D}^{2}$ values and hence, genotypes from these clusters can be used in further breeding programme. These results are in conformity with Irene Priyadarshini (1999) and Serene Maragatham Isacs (2002).

Intra cluster distance was minimum in the cluster I (139.24) indicating the diversity between the genotypes of cluster I was less, while cluster II had maximum intra cluster value (223.20) which revealed the existence of diverse genotypes (Table 3 ).

The cluster mean values for different characters are presented (Table 4). Regarding the mean performance of cluster, cluster IV genotypes had the highest mean for hull content (30.91) and oil content (40.43) with desirable plant height while cluster II (447.28 $\mathrm{kg} / \mathrm{ha}$ ) recorded the highest mean values for oil yield. A similar result was reported by 
Serene Maragatham Isacs (2002). The cluster VII and cluster VIII were recorded highest mean values for seed yield per plant, oil content and oil yield with earliness to flower (Vishnuvardhan Reddy et al., 2005).

Table.1 List of parental lines used to study morphological genetic diversity

\begin{tabular}{|l|l|c|l|}
\hline SI No & Parental lines & SI No & Parental lines \\
\hline \multicolumn{2}{|c|}{ I Restorer lines } & 24 & RCR-60P \\
\hline 1 & GKVK-3 & 25 & RHA-88 \\
\hline 2 & RHA-95-C-2 & 26 & X-15-NB-10 \\
\hline 3 & RHA-278 & 27 & GKVK-1 \\
\hline 4 & RHA-95-C-1 & 28 & RHA-6D-5-3-5 \\
\hline 5 & RHA-272-II & 29 & RHA-93 \\
\hline 6 & RHA-348 & 30 & RHA 6D-5-3-9 \\
\hline 7 & LTRR-822 & 31 & RHA-GK \\
\hline 8 & RHA-94 & 32 & RHA-86 \\
\hline 9 & RHA-284 & 33 & RHA-207 \\
\hline 10 & RHA-297 & \multicolumn{2}{|c|}{ II Maintainer lines } \\
\hline 11 & RHA-859 & 34 & CMS-336B \\
\hline 12 & RHA-91 & 35 & CMS-343B \\
\hline 13 & RHA-92 & 36 & CMS-109B \\
\hline 14 & M17-R & 37 & CMS-339B \\
\hline 15 & RHA-90 & 38 & CMS-850B \\
\hline 16 & MR-1 & 39 & CMS-125B \\
\hline 17 & RHA-273 & \multicolumn{2}{|c|}{ III Diversified CMS lines } \\
\hline 18 & RHA-378 & 40 & ARG-6-3-1-4 \\
\hline 19 & RHA-589 & 41 & PKUZ \\
\hline 20 & GKVK-2 & 42 & MUT2-8-3-2 \\
\hline 21 & RHA-272-I & 43 & PRUN 29 \\
\hline 22 & RHA-183 & 44 & ARG 3 \\
\hline 23 & RHA-6D-1 & 45 & ARG-2-1-2 \\
\hline
\end{tabular}

Table.2 Distribution of genotypes into different clusters

\begin{tabular}{|c|c|l|}
\hline Custer number & $\begin{array}{c}\text { Number of } \\
\text { genotypes }\end{array}$ & \multicolumn{1}{c|}{ Name of the genotypes in each cluster } \\
\hline & & $\begin{array}{l}\text { MR-1, RHA-183, RHA-589, RHA-348, GKVK-2, RHA-90, CMS-850B, } \\
\text { LTRR-822, RHA-297, RHA-272-II, RHA-95-C-1, RHA-284, M17-R, } \\
\text { RCR-60P, RHA-378, RHA-6D-5-3-5, CMS-125B, RHA-273, RHA-94, } \\
\text { RHA-88, RHA 6D-5-3-9, RHA-92, GKVK-1, RHA-272-I, RHA-GK, } \\
\text { RHA-86, RHA-859, RHA-93, GKVK-3, RHA-95-C-2, RHA-6D-1 and } \\
\text { RHA-278 }\end{array}$ \\
\hline I & 32 & $\begin{array}{l}\text { CMS-339B, ARG-2-1-2, CMS-343B, CMS-336B, X-15-NB-10, PRUN- } \\
\text { 29, ARG 3, ARG6-3-1-4 and PKUZ }\end{array}$ \\
\hline II & 9 & RHA-91 \\
\hline III & 1 & RHA-207 \\
\hline IV & 1 & CMS-109B \\
\hline V & 1 & MUT2-8-3-2 \\
\hline VI & 1 &
\end{tabular}


Table.3 Inter and Intra cluster $\mathrm{D}^{2}$ values for six clusters formed by 45 genotypes

\begin{tabular}{|c|c|c|c|c|c|c|}
\hline Clusters & I & II & III & IV & V & VI \\
\hline I & 139.24 & 344.10 & 241.49 & 320.05 & 526.70 & 280.56 \\
\hline II & 344.10 & 223.20 & 582.26 & 652.80 & 344.84 & 350.81 \\
\hline III & 241.49 & 582.26 & 0.00 & 456.68 & 746.38 & 441.00 \\
\hline IV & 320.05 & 652.80 & 456.68 & 0.00 & 1204.09 & 196.28 \\
\hline V & 526.70 & 344.84 & 746.38 & 1204.09 & 0.00 & 894.01 \\
\hline VI & 280.56 & 350.81 & 441.00 & 196.28 & 894.01 & 0.00 \\
\hline
\end{tabular}

Table.4 The cluster mean analysis of 11 quantitative characters for six clusters in sunflower (parents)

\begin{tabular}{|c|c|c|c|c|c|c|c|c|c|c|c|}
\hline $\begin{array}{l}\text { Cluster } \\
\text { number }\end{array}$ & $\begin{array}{c}\text { Days to } \\
50 \% \\
\text { flowering }\end{array}$ & $\begin{array}{c}\text { Plant } \\
\text { height } \\
\text { (cm) }\end{array}$ & $\begin{array}{c}\text { Head } \\
\text { diameter } \\
(\mathrm{cm})\end{array}$ & $\begin{array}{c}\text { Stem } \\
\text { diameter } \\
(\mathrm{cm})\end{array}$ & $\begin{array}{c}\text { Seed } \\
\text { yield } \\
\text { per } \\
\text { plant } \\
\text { (g) }\end{array}$ & $\begin{array}{c}100 \\
\text { seed } \\
\text { weight } \\
\text { (g) }\end{array}$ & $\begin{array}{c}\text { Hull } \\
\text { content } \\
(\%)\end{array}$ & $\begin{array}{c}\text { volume } \\
\text { weight } \\
(\mathrm{g} / 100 \mathrm{ml})\end{array}$ & $\begin{array}{c}\text { Oil } \\
\text { content } \\
(\%)\end{array}$ & $\begin{array}{c}\text { Oil } \\
\text { yield } \\
(\mathbf{k g} / \mathbf{h a})\end{array}$ & $\begin{array}{c}\text { Seed } \\
\text { filling } \\
\text { per } \\
\text { cent } \\
(\%)\end{array}$ \\
\hline I & 58.39 & 101.05 & 8.96 & 1.69 & 8.33 & 3.45 & 29.47 & 45.60 & 38.72 & 179.02 & 90.84 \\
\hline II & 56.39 & 122.80 & 13.88 & 1.98 & 20.71 & 5.06 & 30.64 & 42.11 & 38.63 & 447.28 & 89.78 \\
\hline III & 64.50 & 95.40 & 6.10 & 1.62 & 4.50 & 2.24 & 30.11 & 41.76 & 34.84 & 86.88 & 91.39 \\
\hline IV & 59.00 & 46.00 & 8.40 & 1.11 & 5.00 & 2.64 & 30.91 & 40.91 & 40.43 & 112.27 & 86.86 \\
\hline $\mathbf{V}$ & 62.00 & 177.50 & 13.00 & 2.02 & 18.10 & 5.25 & 22.64 & 40.88 & 39.90 & 401.13 & 93.59 \\
\hline VI & 50.00 & 71.70 & 13.30 & 1.56 & 15.60 & 4.56 & 25.30 & 41.02 & 38.06 & 329.81 & 90.96 \\
\hline
\end{tabular}

Based on cluster mean values for a given characters, we can select highly divergent genotypes from the respective clusters and can be used in hybridization work.

The genotypes MUT2-8-3-2 (cluster VI) recorded early flowering, while RHA-91, which was included in cluster III recorded maximum mean value for oil content and CMS109B (Cluster V) showed maximum mean value for oil yield and seed filling per cent and these genotypes could be used as one of the parents in hybridization programme to synthesize high yielding hybrids in sunflower.

Among the characters studied, maximum contribution to divergence was made by plant height, seed yield per plant and oil content. Sankarapandian et al., (1996), Manivannan et al., (2003), Ramasubramanyam et al., (2003), Reddy et al., (2005), Asish et al., (2007) and
Punitha et al., (2010) reported maximum contribution to divergence by seed yield. Plant height contributed to divergence in the study carried out by Sankarapandian et al., (1996), Manivannan et al., (2003), Asish et al., (2007) and Punitha et al., (2010) similarly Oil content contributed to genetic divergence in the study carried out by Asish et al., (2007) and Punitha et al., (2010).The present study revealed that the selection of parents must be used on the wider inter cluster distance and superior mean performance for yield and yield components.

\section{References}

Anuradha, N., Ramakumar, P.V., Vishnuvardhan Reddy, A. and Durga Rani, C.H.V. (2004). Genetic Divergence in sunflower (H. annuus L.) The Andhra Agric. J., 51(1\&2): 39-43. 
Asish, K. B., Manivannan, N. and Vindhya Varman, P., 2007, Cluster analysis of yield traits in sunflower (Helianthus annuus L.). Madras Agric. J., 94:27-31.

Irene Priyadarshini, D.V., 1999. Genetic analysis of variability in exotic sunflower (Helianthus annuus L.). M.Sc. (Ag.) Thesis, Tamil Nadu Agricultural University, Coimbatore.

Loganathan, P., Gopalan, A. and Manivannan, N. 2006. Genetic divergence in sunflower (Helianthits annuus L). Research on Crops, 7(1): 198-201.

Mahalakshmi, P., Vidhyavathi, R., Manivannan, N. and Muralidharan, V. 2006. Genetic Divergence in sunflower. Agric. Sci. Digest, 26(2): 138-140.

Mahalanobis, P.C., 1936. On the generalized distance in statistics. In: Proc. Nat. Int. Sci. India, 132: 49-55.

Manivannan, N., Murilidharan, V. and Subbalakshmi, B., 2003. Genetic divergence in sunflower. Agri. Sci. Dig., 23(2): 125-127.

Murty, B.R., and Arunachalam, V. 1966. The nature of divergence in relation to breeding systems in some crop plants. Indian J. Genet. Plant Breed, 26: 188198.

Punitha, B., Vindhiyavarman, P. and Manivannan, N., 2010. Genetic divergence study in sunflower (Helianthus annuus L.). Electronic Journal of Plant Breeding, 1(4): 426430.
Rama subrahmanyam, S.V., Sudheer kumar, S. and Ranganatha, A.R.G., 2003. Genetic divergence for seed parameters in sunflower (Helianthus annuus L.) Helia, 26:73-80

Rao, C.R., 1952. Advanced statistical methods in biometrical research. John Wiley and Sons Inc., New York. p. 390.

Reddy, A., Reddy, R. N. and Nagaraj, G., 2005. Genetic divergence for seed yield and its components traits in sunflower, Heliantus annuus L. germplasm accessions. J. Oilseeds Res., 22 (2): 313-316.

Reddy, R.S., Dangi, K.S., Reddy, A.V. and Kumar, S.S. 2004. Genetic divergence in newly developed sunflower (Helianthus annuus L.). J. Oilseeds Res., 21(1): 166-167.

Sankarpandian, R., Muppidathi, N., Rajarathinam, S. and Chidambaram, S., 1996. Genetic divergence in sunflower. Madras Agric. J., 83: 637-639.

Serene Maragatham Isacs. 2002. Genetic analysis and association of molecular marker with fertility restoration in sunflower (Helianthus annuus L) Ph.D. Thesis, Tamil Nadu Agricultural University, Coimbatore

Thoday, J.M., 1960. Effect of disruptive selection. In coupling and repulsion. Heredity, 14: 35-39. Cluster analysis of yield traits in sunflower (Helianthus annuus L.)

\section{How to cite this article:}

Nandini, C., Y.G. Shadakshari, Pushpa Doddaraju, K.T. Puttarangaswamy and Vijay Kumar. 2017. Genetic Diversity Analysis in Diversified CMS and Restorer Lines in Sunflower (Helianthus annuus L.). Int.J.Curr.Microbiol.App.Sci. 6(10): 3185-3189. doi: https://doi.org/10.20546/ijcmas.2017.610.373 